\title{
Valuation of Marine Plastic Pollution in the European Arctic: Applying an Integrated Choice and Latent Variable Model to Contingent Valuation
}

Authors:

Tenaw G. Abate ${ }^{\mathrm{a}^{*}}$, Tobias Börger ${ }^{\mathrm{b}}$, Margrethe Aanesen ${ }^{\mathrm{c}}$, Jannike Falk-Andersson ${ }^{\mathrm{d}}$, Kayleigh J. Wyles ${ }^{\mathrm{e}}$ and Nicola Beaumont ${ }^{\mathrm{f}}$

Affiliations:

${ }^{a}$ NORCE Norwegian Research Centre AS Sykehusvn 21, N-9294, Troms $\varnothing$, Norway. Email teab@norceresearch.no ${ }^{*}$ Corresponding author

${ }^{\mathrm{b}}$ Economics Division, University of Stirling, Stirling, UK. Email tobias.borger@stir.ac.uk

${ }^{c}$ Norwegian College of Fishery Science, University of Troms $\varnothing$, Troms $\emptyset$, Norway. Email: margrethe.aanesen@uit.no

${ }^{\mathrm{d}}$ Salt Lofoten AS, Tromsø, Norway. Email: jannike@ salt.nu

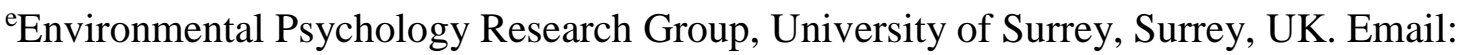

k.wyles@surrey.ac.uk

fPlymouth Marine Laboratory, Plymouth, UK. Email: nijb@pml.ac.uk

Accepted refereed manuscript of:

Abate TG, Börger T, Aanesen M, Falk-Andersson J, Wyles KJ \& Beaumont N (2020) Valuation of marine plastic pollution in the European Arctic: Applying an integrated choice and latent variable model to contingent valuation. Ecological Economics, 169, Art. No.: 106521.

DOI: https://doi.org/10.1016/j.ecolecon.2019.106521

(C) 2019, Elsevier. Licensed under the Creative Commons Attribution-NonCommercial-NoDerivatives 4.0 International http://creativecommons.org/licenses/by-nc-nd/4.0/ 


\begin{abstract}
Despite its remoteness, marine plastic pollution is a significant environmental problem in the Arctic. In Svalbard, for example, plastics are found on the shorelines, in the water column, on the ocean floor and in the ice. Organisms have been observed to be entangled in nets and ingestion of plastics has been documented in a range of organisms. Notably almost all Arctic bird species have been found to have ingested plastic, with Northern fulmars being particularly affected, with $89 \%$ of samples recorded as having ingested plastic. Identification and valuation of ecosystem services affected by marine plastic pollution can provide input for decision makers in evaluating and comparing management policies concerning this unique environment. This study employs the contingent valuation method (CVM) for eliciting the willingness to pay (WTP) of Norwegian households for reducing marine plastic pollution around the archipelago of Svalbard. An Integrated Choice and Latent Variable model (ICLV) is employed to explore attitudinal determinants of WTP. We find an average WTP for an initiative to reduce marine plastics of NOK 5,485 (US\$642) per household per year. The ICLV results reveal that people who are relatively more concerned about marine plastic pollution and who deem the proposed initiative effective are willing to pay more (up to $85 \%$ and $50 \%$, respectively). The use of ICLV models in CVM and recommendations for future research are discussed.
\end{abstract}

JEL: Q51, Q53, Q57

Key words: Arctic; Contingent valuation; Marine debris; Marine litter; Non-market valuation; Plastic waste 


\section{Introduction}

The issue of marine litter, particularly marine plastic pollution, has received increasing global attention. For example, the United Nations (UN) recently initiated the Global Partnership on Marine Litter to bring together governments, non-governmental organizations (NGOs), academia, and the private sector to find solutions to reduce the extent of marine litter ${ }^{1}$. The UN Environment has also launched 'The Clean Seas' campaign aiming to eliminate major sources of marine litter by 2022 focusing on single-use plastic and micro-plastics in cosmetics ${ }^{2}$. At more national level, combating marine litter is a key priority for Norway and the government has allocated NOK 280 million (US\$34 million) for the international fight against marine litter in $2018^{3}$.

The Arctic environment is unique, but also highly vulnerable to climate change and anthropogenic pollution (AMAP, 2015; Ford et al., 2006). Marine litter is a key component of anthropogenic pollution. Studies have shown that the amount of litter in the Arctic, particularly around the Svalbard region, has been increasing during the last few decades (Bergmann et al., 2016; Bergmann and Klages, 2012; Tekman et al., 2017). High levels of marine litter have been found in the Svalbard and Barents Sea area at the sea floor (Buhl-Mortensen and BuhlMortensen, 2017), in the water column (Lusher et al., 2015), in ice cores from the Arctic basin (Obbard et al., 2014), and along the shores (Bergmann et al., 2017; MOSJ, 2015). Similar to other areas of the world, the overwhelming portion of marine litter found in Svalbard is plastics which accounts for more than $80 \%$ of the total litter (Bergmann et al., 2017).

Marine plastics, as the main component of marine litter around Svalbard, poses a threat to many of the ecosystem services (i.e. the benefits people obtain from nature) provided by marine and coastal environment in the region (Beaumont et al., 2019). Accounts of impacts of marine plastic pollution in and around Svalbard include: beaches and shorelines around the islands are littered with plastics which could affect aesthetic amenities (Bergmann et al., 2017); animals, such as polar bears, seals, reindeer or porpoises, have been observed to be entangled in nets and ropes (Hallanger and Gabrielsen, 2018); seabirds, particularly northern fulmars, are significantly affected through the ingestion of plastic pieces (Trevail et al., 2015a); and microplastics (very small pieces of plastic less than $5 \mathrm{~mm}$ in diameter) are detected in more than $90 \%$ of water samples taken from the region (Lusher et al., 2015; Trevail et al., 2015b).

Measures to limit the amount of marine plastics entering the waters around Svalbard and reducing the amount of existing marine plastic pollution will lead to an alleviation of the above impacts. Such alleviation represents an improvement in welfare since the ecosystem services of the marine and coastal environment would be restored. However, to the best of our knowledge, no scientific study has quantified the welfare loss incurred due to marine plastic pollution in this unique environment. Quantification of the environmental benefits of reducing marine plastic pollution can provide an important input for decision makers when evaluating and comparing management policies concerning the Arctic.

\footnotetext{
${ }^{1}$ https://www.unenvironment.org/explore-topics/oceans-seas/what-we-do/addressing-land-basedpollution/global-partnership-marine

2 https://www.cleanseas.org/

${ }^{3}$ https://www.regjeringen.no/en/aktuelt/marine_litter/id2601087/
} 
Previous studies on valuations of marine pollution have been dominated by valuations of oil spills (e.g. Alvarez et al., 2014; Bishop et al., 2017; Carson et al., 1992; Lee et al., 2018; Liu et al., 2016; Loureiro et al., 2009; Van Biervliet et al., 2005). Oil spill incidents usually attract wider media coverage and catch high government and public attention. In some cases, oil spill incidents involved court litigations (Carson et al., 2003; Petrolia, 2015). Other types of marine pollution that have been valued using stated preference methods include: eutrophication and algal blooms (e.g. Ahtiainen et al., 2014; Atkins and Burdon, 2006; Taylor and Longo, 2010; Żylicz, 1995), acidification (Rodrigues et al., 2013), and thermal discharge from nuclear power generation (Min et al., 2017). Although valuation studies solely on marine litter are very few ( Brouwer et al., 2017; Smith et al., 1997), there are many studies which considered marine litter as one component of the valuation exercise (Aanesen et al., 2018; Beharry-Borg and Scarpa, 2010; Blakemore and Williams, 2008; Blakemore et al., 2000; Loomis and Santiago, 2013).

Against this background, this study employs the contingent valuation method (CVM) to assess the value of reducing marine plastic pollution and its resultant impacts on the marine environment around Svalbard. The objective of the present study is twofold: $(i)$ to derive the willingness to pay (WTP) of the Norwegian public for a reduction of marine plastic pollution around Svalbard, and (ii) to analyze the determinants of WTP using an integrated choice and latent variable (ICLV) model (Ben-Akiva et al. 2002). With respect to the first objective, the study elicits the WTP of Norwegian households for reducing marine plastic pollution around the archipelago of Svalbard. Since the benefits of reducing marine plastic pollution can be interpreted as a quantification of the costs of this impact, this study responds partly to an assessment by Newman et al.(2015) highlighting the challenges of measuring the total economic costs of marine litter. Consequently, this is the first valuation study that measures the impact of marine plastic pollution on the unique environment of the Arctic. The present study is also novel as unlike previous marine litter valuation studies which were mainly focused on the impact on aesthetic amenities, and hence on beach visitors (e.g. Beharry-Borg and Scarpa, 2010; Loomis and Santiago, 2013; Östberg et al., 2012; Smith et al., 1997), this study also considers other impacts of marine plastic litter such as entanglement of animals, ingestion of plastic pieces by seabirds, and the presence of microplastics that can accumulate up the food chain.

As only a small minority of Norwegians will have visited Svalbard, the values elicited in this study are mainly non-use values. In this situation a validation of the WTP results based on an identification of the determinants of WTP is particularly important. The second objective of the paper is, therefore, to explore how attitudes pertaining to the concern for the environmental issue, and important and effectiveness of the proposed countermeasures affect the WTP for reductions in marine plastic pollution using an ICLV model. The ICLV approach has increasingly been used in stated preference valuations studies with repeated multinomial (Czajkowski et al., 2017a; Grilli et al., 2018; Hess and Beharry-Borg, 2012; Taye et al., 2018; Zawojska et al., 2019) or repeated binary choice formats (Czajkowski et al., 2017b). The present study, however, uses an ICLV model with single binary choice contingent valuation data, an approach which to the best of our knowledge, has so far only been used by Kassahun et al. (2016). The present paper explores whether accounting for attitudes as determinants of WTP allows for a more nuanced validation of stated WTP, which is particularly important in this case given the likely emotive and pressing nature of marine plastic pollution. The 
additional benefit of this approach is the ability to simultaneously validate the latent variables used to assess the attitudes by examining their relationship with a set of socio-demographic variables.

We find an average WTP for an initiative to reduce marine plastic pollution around Svalbard of NOK 5,485 (US\$642) per household per year, a value much higher than valuations found in similar CVM studies in Norway (Aanesen et al., 2015; Navrud et al., 2017; Noring et al., 2016). ICLV model results suggest that the driver of these high WTP figures might be a strong attitude for preserving the unique ecosystem of Svalbard, as well as the high-profile nature of marine plastic pollution currently in Norway.

The remainder of this paper is structured as follows. Section 2 provides a brief description of the study area and an overview of the extent and origin of plastic pollution in the Arctic, as well as its associated environmental and ecological impacts. Section 3 presents the methodology. Section 4 presents the results which are then discussed in Section 5.

\section{Study Area}

The archipelago of Svalbard is located in the Barents Sea, between the Norwegian mainland and the North Pole (Figure 1). The archipelago has been part of the sovereign territory of the Kingdom of Norway since 1920 in accordance with the Svalbard Treaty ${ }^{4}$. The Svalbard area hosts a highly productive marine ecosystem providing a wide range of ecosystem services including important fisheries, it is a hub for international research and cooperation, a destination for tourism and cultural- and wildlife experiences, and a source for documentaries which are appreciated world-wide. Moreover, as many organisms in the Arctic are adapted to extreme weather conditions, their genetic properties are useful for bioprospecting (Svenson, 2013)

\footnotetext{
${ }^{4}$ https://www.jus.uio.no/english/services/library/treaties/01/1-11/svalbard-treaty.xml The Svalbard Treaty provides for Norwegian sovereignty over Svalbard. However, it also imposes a few limitations and provides certain rights for other signatories.
} 


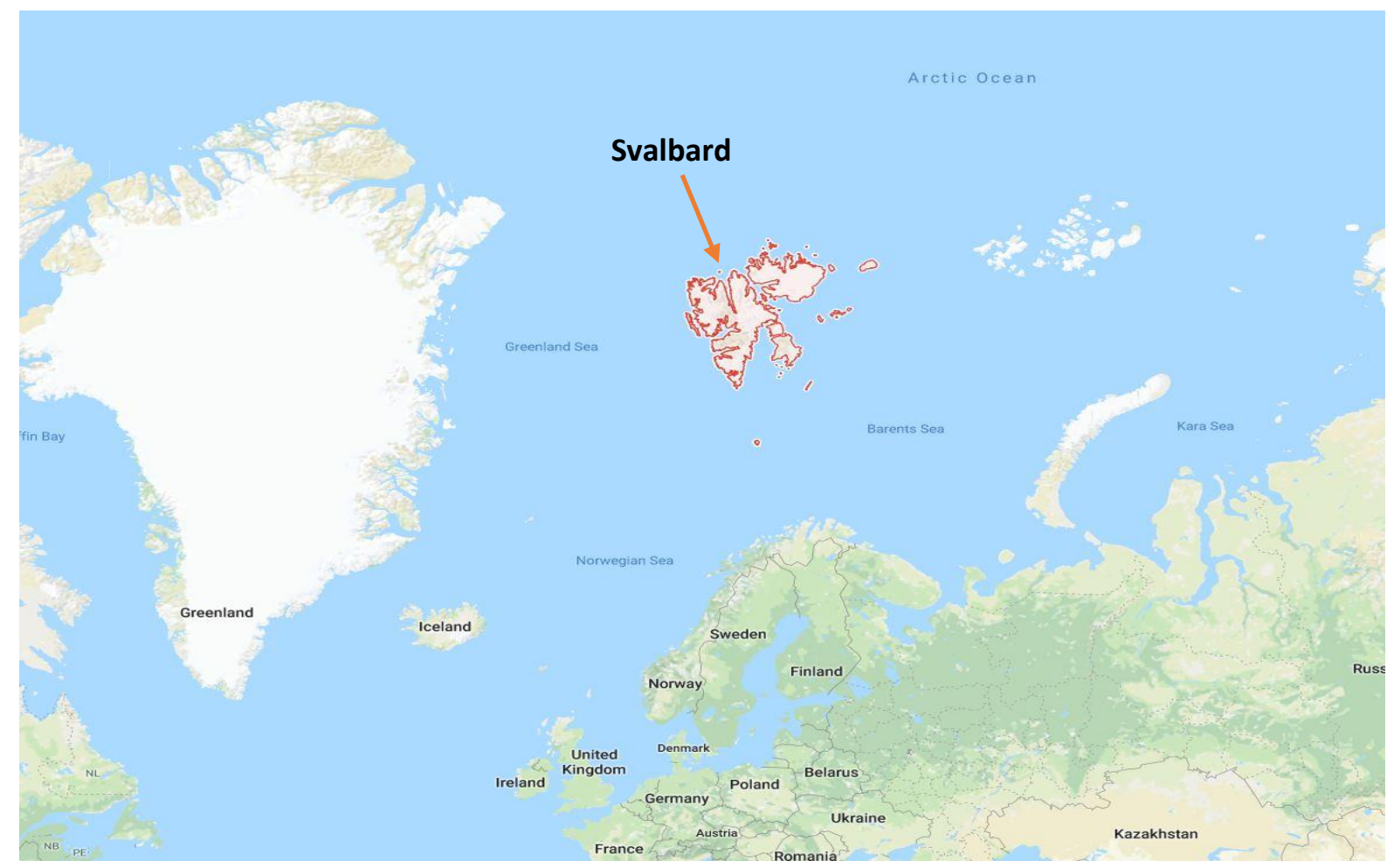

The Arctic is one of the least polluted areas of wilderness on earth, with few local sources of anthropogenic pollution due to limited human activities (Halpern et al., 2008). However, the Arctic acts as a sink for certain pollutants transported through air, rivers and ocean currents from distant sources. Furthermore, low temperatures and low biological activity result in pollutants being released in, or transported to, the Arctic persisting in the environment for a long time (AMAP, 2015).

An emerging pollutant worldwide as well as in the Arctic is marine plastic litter which has received increasing global attention as the magnitude and severity of the problem has become more evident (Thevenon et al., 2015). Jambeck et al. (2015) estimate that 4.8 to 12.7 million metric tons of plastics entered the oceans from land-based sources in 2010 alone. Using both OSPAR beach litter data and two different citizen science data sets, Falk-Andersson et al. (2019) show that plastic is the dominating litter material constituting $75-99 \%$ of the total litter composition on Norwegian beaches. Particularly for Svalbard, Bergmann et al. (2017) report that marine plastic litter accounted for more than $80 \%$ of the marine litter found around the archipelago ${ }^{5}$.

The large fishery taking place in the region is believed to be a major contributor of marine plastic litter around Svalbard. In 2016, volunteers at Svalbard collected 93 cubic meters of litter around the islands through the project Clean-up Svalbard (SALT, 2017). A qualitative analysis of a sample of beach litter indicated that a large proportion of the litter originated from fisheries activities, but also from other marine activities, such as shipping, ship-based tourism and scientific expeditions (SALT, 2017). Bergmann et al. (2017) analyzed litter from six Svalbard

\footnotetext{
${ }^{5}$ Drift wood was not included in the analysis.
} 
beaches collected through citizens science and found that fisheries-related plastic, such as ropes, buoys, floaters, nets and pieces thereof, accounted for $44-100 \%$ of the litter mass. The Association of Arctic Expedition Cruise Operators (AECO) report that nearly 60-80\% of collected wastes in 2016 and 2017 originated from the fisheries industry. ${ }^{6}$

The full ecological and social impacts of marine plastic pollution around Svalbard are unknown mainly because of lack of scientific studies and proper documentation of the impact of plastic pollution. However, the valuation study presented here focuses on four key negative consequences of marine plastic pollution around Svalbard that have been evidenced. Firstly, Bergmann et al. (2017) documented that on average 100 grams of plastics are found per meter square of beach around Svalbard. A littered environment may negatively affect the rapidly developing tourism industry in the region because the aesthetic amenities of beaches and shorelines will be diminished (Wyles et al., 2016).

Secondly, animals including charismatic species such as polar bears, seals, reindeer or porpoises have been reported to be entangled in nets and ropes (Hallanger and Gabrielsen, 2018). A personal communication with the Environmental Department of the Office of the Governor of Svalbard indicated that on average 20-25 cases of animal entanglements are reported every year. However, it is believed that the actual number of entangled animals may be significantly higher because many cases of entanglements are not observed and hence go unreported.

Thirdly, plastic pieces can be ingested by seabirds potentially causing diminished food stimulus, internal injuries, blockage of the intestinal tract, and contaminant transfer from ingested plastic, resulting in sub lethal effects such as reduced reproductive potential and in some cases premature death. Research undertaken on the ecological impact of marine plastic in the Arctic shows a significant bias towards birds, with evidence to demonstrate a substantial proportion of Arctic seabirds have some plastic in their stomachs. Northern Fulmars are considered to be the most severely affected, with up to $89 \%$ of samples having plastic in their stomachs (Poon et al., 2017; Trevail et al., 2015a) Thick-billed murres (Provencher et al., 2010), little auks (Fife et al., 2015), black legged kittiwakes and great cormorants (Acampora et al., 2017) have all also been found to have ingested plastic.

Fourthly, very small pieces of plastic less than $5 \mathrm{~mm}$ in size are called microplastics. Microplastics can be ingested by small marine organisms and passed on to animals that eat them, including fish, mammals, birds and possibly even humans. (Lusher et al., 2015) documented that microplastics were found in 20 out of 21 (95\%) of the surface samples collected from the top $16 \mathrm{~cm}$ of seawater in the Arctic. They also reported that $93 \%$ of subsurface water samples contained microplastics. Although some studies documented negative impacts of microplastics on zooplankton (see Cole et al., 2013; Sun et al., 2017), the full consequences on the entire food chain are not yet known.

${ }^{6}$ https://www.aeco.no/guidelines/cleanup-guidelines/ 


\section{Methodology}

\subsection{Development of valuation scenario and survey design}

A nationally representative survey was conducted online using the Contingent Valuation Method (CVM). The single-bounded dichotomous choice (SBDC) elicitation format was employed to collect WTP responses for a hypothetical marine plastics pollution clean-up and prevention initiative based at Svalbard. The questionnaire and valuation scenario were developed in a series of iterative steps following the recommendations by Johnston et al. (2017). This involved literature review, expert consultation, focus group discussions (three in Svalbard, one in Troms $\varnothing$, Northern Norway), test interviews in Svalbard and Troms $\varnothing$ and three online pilot surveys. The valuation survey was originally intended to employ a discrete choice experiment (Kanninen, 2007) to examine the preferences for different types of impacts of reducing plastic pollution (listed in section 2). However, after conducting two pilot surveys it became clear that respondents were not trading off different impacts against each other and that, instead, they regarded the proposed initiative to reduce marine plastic pollution as a single package of benefits. Respondents commented that it was hardly convincing to vary the levels of different impacts independently. Consequently, the CVM using the SBDC format was adopted. An additional methodological benefit of the SBDC format is its desirable property of incentive-compatible revelation of preferences (Carson et al., 2014; Carson and Groves, 2007).

The final survey included questions pertaining to a) respondents' views about Svalbard and experience with it; b) respondents' knowledge of and attitudes towards marine plastic pollution; c) the valuation scenario introducing an initiative to reduce the impacts of marine plastic pollution around Svalbard including the SBDC WTP question and related attitudinal questions; d) respondents' everyday routines and behaviors related to plastic use and waste management, and e) demographic information about respondents.

For the valuation scenario, participants were presented with information representing the four scientifically reported impacts noted in Section 2. Table 1 reports the anticipated changes resulting from the initiative that respondents were presented with. Respondents were informed that in the current situation, plastic pollution around Svalbard impacts beaches and shorelines, various terrestrial and marine mammals, certain bird species and the seawater in general through the presence of microplastics. Presenting a clear baseline and projected future state after implementation of the initiative follows recent recommendations for the design of stated preference surveys (Johnston et al., 2017).

Table 1: Initiative characteristics and the tax amount vector

\begin{tabular}{|c|c|c|}
\hline Characteristics & Current situation & With the initiative \\
\hline Impact on beaches & $\begin{array}{l}100 \text { grams of plastics per meter } \\
\text { square of beach }\end{array}$ & $\begin{array}{l}10 \text { grams of plastics per meter } \\
\text { square of beach }\end{array}$ \\
\hline Impacts on mammals & $\begin{array}{l}60 \text { seals, reindeer or porpoises get } \\
\text { entangled in nets and ropes }\end{array}$ & $\begin{array}{l}10 \text { seals, reindeer or porpoises } \\
\text { get entangled in nets and ropes }\end{array}$ \\
\hline Impact on birds & $\begin{array}{l}90 \% \text { of seabirds have pieces of } \\
\text { plastics in the stomachs }\end{array}$ & $\begin{array}{l}10 \% \text { of seabirds have pieces of } \\
\text { plastics in the stomachs }\end{array}$ \\
\hline Impact on microplastics & $\begin{array}{l}90 \% \text { of water samples contain } \\
\text { microplastics }\end{array}$ & $\begin{array}{l}10 \% \text { of water samples contain } \\
\text { microplastics }\end{array}$ \\
\hline Tax (in NOK) & 0 & $500,1500,2700,4400,7000$ \\
\hline
\end{tabular}

Note: $1 \mathrm{USD} \approx 8.5 \mathrm{NOK}$ 
The payment vehicle was a compulsory tax. Participants in focus groups and pilot surveys did not have any objection against the payment vehicle suggesting that it is realistic (Mitchell and Carson, 1989). Following arguments for annual payment (Egan et al., 2015) and payments at household level (Lindhjem and Navrud, 2009), the tax was presented to be collected annually from every Norwegian household. The tax amounts were selected based on the results of the pilot surveys and previous related CV studies in Norway (Navrud et al, 2017; Noring et al, 2016).

To minimize hypothetical bias, respondents were reminded about a number of important issues around the financing of the initiative (Arrow et al., 1993). First, respondents were told that since marine plastic pollution around Svalbard comes from many sources, including other countries, the initiative will be able to reduce, but not eliminate, all impacts of marine plastic pollution. Second, they were informed that the implementation of the initiative is costly and cannot be financed out of existing public funds, instead the costs will have to be covered through a new, annual tax to be collected from all households in Norway. Third, respondents were prompted with examples of various reasons that might make them not want to support the initiative, as well as reasons that would make them vote against paying for the initiative even if they would like it to be carried out. Fourth, they were also reminded to think about their limited income and resources and alternative goods or services which they could spend their disposable income on instead. Ethical approval for the survey materials was sought and obtained from the Norwegian Centre for Research Data (NSD). The study also adheres to the British Psychological Society's Code of Human Research Ethics.

\subsection{Model estimation}

SBDC data can be analyzed using the random utility framework (Haab and McConnell, 2003; Hanemann, 1984). Respondent $i$ can choose between two options $j$ : the state that prevails after the proposed initiative has been implemented with a certain cost $t_{i}(j=1)$ and the current situation with neither initiative or cost $(j=0)$. If indirect utility of respondent $i$ in either situation is written as

$$
U_{i j}=U_{j}\left(y_{i}, X_{i}, \varepsilon_{i j}\right)
$$

where $y_{i}$ is discretionary income, $X_{i}$ is a vector of respondent characteristics and $\varepsilon_{i j}$ is the unobserved component of the indirect utility, the probability of respondent $i$ preferring the initiative with the required payment of $t_{i}$, i.e. the probability of answering 'yes' to the SBDC question, is

$$
\operatorname{Pr}\left(\text { yes }_{i}, t_{i}\right)=\operatorname{Pr}\left[U_{i 1}\left(y_{i}-t_{i}, X_{i}, \varepsilon_{i 1}\right)>U_{i 0}\left(y_{i}, X_{i}, \varepsilon_{i 0}\right)\right],
$$

where $U_{i 1}(\cdot)$ is the level of indirect utility with and $U_{i 0}(\cdot)$ without the proposed initiative. Assuming further a linear utility function and the difference in the unobserved components of indirect utility $\Delta \varepsilon_{i}=\varepsilon_{1 i}-\varepsilon_{0 i}$ to be independent and identically distributed and following a normal distribution, the probability of accepting the tax amount for the proposed initiative ("yes") for respondent $i$ can be estimated with the binary probit model as

$$
\operatorname{Pr}\left(\text { yes }_{i} \mid X_{i}, t_{i}\right)=\Phi\left(\frac{\beta X_{i}}{\sigma}-\frac{\gamma}{\sigma} t_{i}\right)
$$


where $\Phi(\cdot)$ is the cumulative standard normal, $\sigma$ is the standard deviation of the error term, and $\beta$ and $\gamma$ are coefficients to be estimated. Note that $X_{i}$ contains a constant.

To explore how latent variables measuring attitudes regarding marine plastics pollution and the propose initiative affect WTP, the above model is augmented to an ICLV model (Ben-Akiva et al., 2002; Hess and Beharry-Borg, 2012). This approach accounts for potential measurement error when attitudes of respondents, which can only be measured imprecisely, are included directly as covariates in choice or WTP models (Czajkowski et al., 2017b). A typical ICLV model consists of three components: the choice equation based on the binary choice model described above, a series of measurement equations linking each latent variable to its respective indicators, and a series of structural equations identifying covariates of the latent variables.

The binary choice model can be augmented by assuming that a vector of latent variables $Q_{i}=$ $\left(q_{i 1}, \ldots, q_{i k}\right)$ measuring the attitudes of interest and being assumed to affect indirect utility of respondent $i$ 's two options $U_{i j}=U_{j}\left(y_{i}, X_{i}, Q_{i}, \varepsilon_{i j}\right)$. The augmented probit model is then

$$
\operatorname{Pr}\left(y e s_{i} \mid X_{i}, Q_{i}, t_{i}\right)=\Phi\left(\frac{\beta X_{i}}{\sigma}+\frac{\delta Q_{i}}{\sigma}-\frac{\gamma}{\sigma} t_{i}\right) .
$$

The $k$ elements of the vector of latent variables are each linked to a set of indicator variables $I_{i k}^{m}$ through measurement equations

$$
I_{k}^{m}=\lambda_{k}^{m} q_{k}+\mu_{k}
$$

where $\lambda_{k}^{m}$ is a coefficient specific to latent variable $k$ and the indicator $m$, and $\mu_{k}$ is an error term specific to this measurement equation. Each latent variable $q_{k}$ can be linked to one or several indicators, which are derived from attitudinal survey questions. For SBDC data, however, models with only one indicator per latent variable are rarely identified, so the analysis will proceed with two indicators per latent variable. Furthermore, in this survey all indicator variables are measured on 5-point Likert response scales, so the links in equation 5 are ordinal probit models.

The third component of the ICLV model is a set of structural equations linking each latent variable $q_{k}$ to a set of demographic covariates $Z_{i}$ :

$$
q_{k}=\rho Z_{i}+\tau_{k}
$$

$Z_{i}$ might or might not overlap or be identical with $X_{i} . \rho$ is a coefficient vector to be estimated and $\tau_{k}$ is an error term assumed to follow a normal distribution. To identify the model, the variance of $\tau_{k}$ for each latent variable is normalized to 1 .

The structure of the full model is outlined by a path diagram in Figure 2. Observed variables are in rectangles and latent variables are in ovals. Two latent variables are included after correlations between indicator variables were examined and exploratory factor analysis was conducted. The first latent variable (CONCERN) measures respondents' level of concern about marine plastic pollution and it also captures the level of importance respondents attach to the proposed initiative. CONCERN is linked to responses to the statements $I_{C O N C E R N}^{1}$ : "I am VERY concerned about the impacts of marine plastic litter"; $I_{\text {CONCERN }}^{2}$ "There are other issues that are more important than marine plastic litter", 
$I_{\text {CONCERN }}^{3}$ : "I think it is really important to take measures to reduce marine plastic litter whatever the cost" and $I_{\text {CONCERN }}^{4}$ : "The proposed improvements are not important to me" on a 5-point agreement scale. The second latent variable, EFFECT measures the extent to which a respondent perceives the effectiveness of the proposed initiative in terms of reducing the impacts of marine plastic pollution around Svalbard. The two indicators for EFFECT are $I_{E F F E C T}^{1}$ : "How effective do you think the initiative will be at reducing the impacts of marine plastic litter?" and $I_{E F F E C T}^{1}$ : "I do not think the taxes collected as part of this initiative will be sufficient to reach the goals described above". Table 2 summarizes responses to the indicator variables.

Figure 2: Path diagram to determine the effect of latent attitudes on WTP

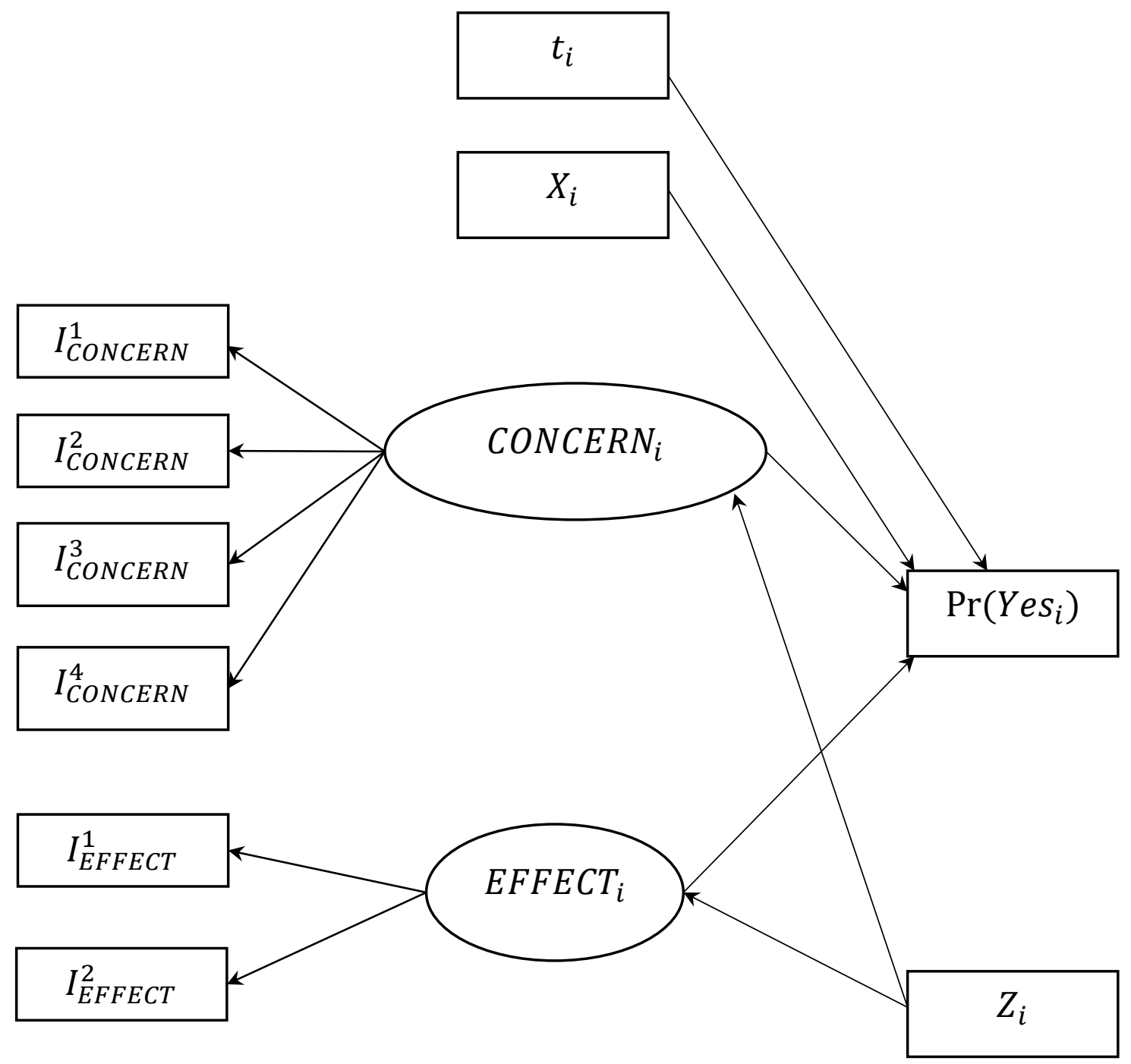


Table 2: Indicator variables for CONCERN and EFFECT

\begin{tabular}{|c|c|c|c|c|c|c|}
\hline \multirow[t]{2}{*}{ Latent Variables } & \multirow[t]{2}{*}{ Indicator Variables } & \multicolumn{5}{|c|}{$\begin{array}{l}\text { Likert-scale responses } \\
\text { (percentage) }\end{array}$} \\
\hline & & SD & D & $\mathbf{N}$ & $\mathbf{A}$ & SA \\
\hline \multirow{4}{*}{ CONCERN } & $\begin{array}{l}\text { I am VERY concerned about the } \\
\text { impacts of marine plastic litter }\end{array}$ & 0.4 & 2.5 & 10.5 & 42.0 & 44.6 \\
\hline & $\begin{array}{l}\text { There are other issues that are more } \\
\text { important than marine plastic litter }\end{array}$ & 4.5 & 25.5 & 57.1 & 14.0 & 3.0 \\
\hline & $\begin{array}{l}\text { I think it is really important to take } \\
\text { measures to reduce marine plastic } \\
\text { litter whatever the cost }\end{array}$ & 2.2 & 7.4 & 23.7 & 41.9 & 24.8 \\
\hline & $\begin{array}{l}\text { The proposed improvements are not } \\
\text { important to me }\end{array}$ & 25.5 & 48.7 & 20.8 & 4.2 & 0.7 \\
\hline \multirow{3}{*}{ EFFECT } & $\begin{array}{l}\text { I do not think the taxes collected as } \\
\text { part of this initiative will be sufficient } \\
\text { to reach the goals described above }\end{array}$ & 6.7 & 22.3 & 37.0 & 24.8 & 9.2 \\
\hline & & $\mathbf{E E}$ & $\mathbf{V E}$ & ME & SE & NE \\
\hline & $\begin{array}{l}\text { How effective do you think the } \\
\text { initiative will be at reducing the } \\
\text { impacts of marine plastic litter? }\end{array}$ & 2.9 & 25.2 & 43.5 & 22.8 & 5.6 \\
\hline
\end{tabular}

Notes: SD - Strongly Disagree; D - Disagree; N - Neither agree nor disagree; A - Agree; SA - Strongly Agree. EE - Extremely Effective; VE - Very Effective; ME - Moderately Effective; SE - Slightly Effective; NE - Not effective at all

Coefficients are estimated using maximum likelihood. Thus, for a given sample of $n$ respondents, the likelihood function is

$$
\begin{aligned}
\mathrm{L}\left(\beta, \gamma, \delta \mid X_{i}, Q_{i}, t_{i}\right) & \\
& =\prod_{i=1}^{n}\left[\Phi\left(\frac{\beta X_{i}}{\sigma}+\frac{\delta Q_{i}}{\sigma}-\frac{\gamma}{\sigma} t_{i}\right)\right]^{y e s_{i}}\left[1-\Phi\left(\frac{\beta X_{i}}{\sigma}+\frac{\delta Q_{i}}{\sigma}-\frac{\gamma}{\sigma} t_{i}\right)\right]^{1-\text { yes }_{i}}
\end{aligned}
$$

where $y e s_{i}$ is a dummy variable taking the value of 1 if the respondent answers yes and 0 otherwise.

Sample mean WTP is computed based on the estimated coefficients by running a probit model only with a constant term and the tax amount $t_{i}$. It can be expressed as

$$
E[W T P]=-\frac{\beta_{0}}{\gamma}
$$

where $\beta_{0}$ is the coefficient of the constant. Confidence intervals of WTP estimates are obtained via bootstrapping (Krinsky and Robb, 1990, 1986). 


\section{Results}

\subsection{Sample characteristics}

The survey was conducted online by the market research company Norstat in June 2018. The data used in this analysis are one of three split samples from a survey for which 10,447 panelists were contacted. In total 1,804 respondents completed the survey, 788 started but never finished and 63 were stopped after the required number of respondents were reached. The questionnaire for the three splits was identical except for the WTP question ${ }^{7}$. Respondents were assigned to one of the three versions of the WTP questions automatically and randomly. The total response rate was $25.4 \%$ and the effective response rate usable in the data was $17.3 \%$. The split sample using the single-bounded dichotomous choice (SBDC) format and used for this analysis consisted of 600 respondents, $48(8 \%)$ were identified as protest respondents ${ }^{8}$ and removed leaving a final sample of 552 respondents. Sample characteristics are displayed in Table 3.

Compared to the national average, the sample for this survey were slightly older and had a higher level of education. It may not be surprising that our sample reported higher education level as the national data from Statistics Norway (SSB) uses data from "vitnemålsdatabasen"9 which asks people the actual years of education, in contrast, this survey asked people to state their highest education and thus may be more sensitive to social desirability i.e. answering higher than the true finished years of education according to SSB. Moreover, a comparison between the education level of our sample and the whole panel of the survey company did not result in a significant difference.

Table 3: Sample characteristics

\begin{tabular}{lllrrr}
\hline \multicolumn{1}{c}{ Variable } & \multicolumn{1}{c}{ Explanation } & No. & Mean & Std. dev. & \multicolumn{1}{c}{ National } \\
\hline \hline Male & Dummy for male respondent & 552 & 0.51 & 0.50 & 0.50 \\
Age & Age (in years) & 552 & $44^{*}$ & 17.21 & $39.2^{*}$ \\
Uni & Hold university degree & 552 & 0.62 & 0.49 & 0.33 \\
$\begin{array}{l}\text { Child } \\
\text { No_Income }\end{array}$ & $\begin{array}{l}\text { Having at least one child } \\
\text { Dummy for preferring not to state }\end{array}$ & 552 & 0.57 & 0.49 & \\
Income & $\begin{array}{l}\text { income } \\
\text { Annual household income before }\end{array}$ & 552 & 0.24 & 0.43 & \\
tax (in thousand NOK) & 420 & $700^{*}$ & 422.96 & $710.2^{*}$ \\
$\begin{array}{l}\text { Env'ntal org. } \\
\text { member }\end{array}$ & $\begin{array}{l}\text { Member of environmental } \\
\text { organization (s) }\end{array}$ & 552 & 0.07 & 0.25 &
\end{tabular}

\footnotetext{
${ }^{7}$ The exact wording of the SBDC elicitation question is "Considering the anticipated results of the initiative outlined before, would you vote for this initiative if the initiative would cost your household an annual tax of NOK XXX for the next ten years?

(1) $\quad \square \quad$ Yes, I would vote for the initiative if it costs my household NOK XXX per year.

(2) $\quad \square \quad$ No, I would not vote for the initiative if it costs my household NOK XXX per year.

In the second treatment, we used the trichotomous choice format (Loomis et al. 1999) where respondents were provided with three options i.e. 'Yes', 'Yes but if the tax is less than the stated amount' and 'Not at all'. In the third treatment, we used the inferred valuation method (Lusk and Norwood 2009) i.e. rather than directly asking respondents' own WTP, we asked them whether they think an average Norwegian household would vote for the initiative given the specified tax amount.

${ }^{8}$ These are respondents who answer 'no' to the elicitation question and strongly agree (on a 5-point Likert scale) to the statements "I already pay enough in taxes" and "I have the right to well preserved marine environments and I should not have to pay extra for it".

${ }^{9}$ Vitnemalsdatabasen is a national database containing upper secondary school diplomas issued since 2000.

https://www.ssb.no/vgogjen
} 
Visited_Svalbard Whether respondents have ever been to Svalbard or not

Notes: ${ }^{a}$ Respondents were asked for annual income before tax because it was observed that respondents had difficulty in remembering their annual net income after tax during piloting. However, the national median income is reported after tax * Indicates median

\subsection{Estimation and determinants of WTP}

We estimated a simple probit model only with a constant and the tax amount. Based on these estimates, mean WTP and the total value of the initiative can be computed. The mean annual WTP for the initiative is NOK 5,485 (USD 642), with a 95\% confidence interval ranging from NOK 4,744 to 6,691 .

To identify determinants of WTP, a probit model with basic socio-demographic characteristics of respondents was estimated (Model 1 in Table 4). Male respondents are less likely to accept the tax amount. Age and probability of a yes response are related in a non-linear way i.e. the probability of accepting the tax amount decreases with age at first and rises again for older respondents. Respondents who do not state their income in the survey (No_Income) are less likely to accept the tax amount ${ }^{10}$; and members of an environmental organization are more likely to support the initiative. The fact that a respondent has been to Svalbard before (Visited_Svalbard) has no significant effect on the probability of a yes response.

Model 2 presents the results of the ICLV model identifying further attitudinal determinants of WTP. The latent variables (CONCERN and EFFECT) are all linked to their respective indicators as shown in Section B (Table 4). Note that the cut-off coefficients for the different levels in these ordinal probit equations are left out for the sake of brevity. In the main choice equation (Section A), the coefficients of all latent variables are positive and significant indicating that respondents who are relatively more concerned about marine plastic pollution (CONCERN), and who believe the proposed initiative will be effective in reducing marine plastic pollution (EFFECT), are willing to pay more.

Table 4: Socio-demographic and attitudinal determinants of WTP

\begin{tabular}{lllll}
\hline & \multicolumn{2}{c}{ Model 1 } & \multicolumn{2}{c}{ Model 2 } \\
\cline { 2 - 5 } & Coef. & Std. Err. & Coef. & Std. Err. \\
\hline \hline A. Main choice equation (binary probit) & & & \\
Tax_1000 a & $-0.172^{* * *}$ & $(0.025)$ & $-0.2783^{* * *}$ & $(0.053)$ \\
Male & $-0.212^{*}$ & $(0.118)$ & $0.752^{* * *}$ & $(0.303)$ \\
Age & $-0.049^{* *}$ & $(0.022)$ & $-0.078^{* *}$ & $(0.038)$ \\
Age_square & $0.0005^{* *}$ & $(0.0002)$ & $0.001^{*}$ & $(0.0004)$ \\
Uni & $0.210^{*}$ & $(0.121)$ & $0.609^{* * *}$ & $(0.229)$ \\
Child & 0.112 & $(0.141)$ & 0.135 & $(0.238)$ \\
NO_Income & $-0.269^{* *}$ & $(0.136)$ & 0.299 & $(0.279)$ \\
Env'ntal org. member & $0.470^{*}$ & $(0.254)$ & -0.653 & $(0.490)$ \\
Visited_Svalbard & 0.236 & $(0.177)$ & 0.254 & $(0.305)$ \\
CONCERN & & & $1.044^{* * *}$ & $(0.190)$ \\
EFFECT & & & $0.843^{* * *}$ & $(0.270)$ \\
cons & $1.951^{* * *}$ & $(0.480)$ & $3.276^{* * *}$ & $(0.909)$ \\
B. Measurement equations & & & & \\
I $\mathbf{C}$ ConCERN $\leftarrow$ CONCERN & & & $1.014^{* * *}$ & $(0.120)$
\end{tabular}

\footnotetext{
${ }^{10} \mathrm{~A}$ model with log-income as independent variable yielded a positive but insignificant effect of income on the probability of a Yes response. Due to the substantial number of missing response on the income variable this model has $\mathrm{n}=420$ and is not directly comparable to Model 1 in Table 5.
} 


\begin{tabular}{lcc}
$\boldsymbol{I}_{\text {CONCERN }}^{2} \leftarrow$ CONCERN & $-0.432^{* * *}$ & $(0.057)$ \\
$\boldsymbol{I}_{\text {CONCERN }}^{\mathbf{3}} \leftarrow$ CONCERN & $1.310^{* * *}$ & $(0.153)$ \\
$\boldsymbol{I}_{\text {CONCERN }}^{\mathbf{4}} \leftarrow$ CONCERN & $-0.758^{* * *}$ & $(0.076)$ \\
$\boldsymbol{I}_{\text {EFFECT }}^{\mathbf{1}} \leftarrow$ EFFECT & $0.487^{* * *}$ & $(0.099)$ \\
$\boldsymbol{I}_{\text {EFFECT }}^{2} \leftarrow$ EFFECT & $-0.595^{* * *}$ & $(0.114)$ \\
\hline C. Structural equation: Covariates of CONCERN & & \\
Male & & \\
Age & $-0.505^{* * *}$ & $(0.107)$ \\
Age_square & $0.039^{* *}$ & $(0.019)$ \\
Uni & -0.0002 & $(0.0002)$ \\
Child & -0.169 & $(0.108)$ \\
NO_Income & 0.040 & $(0.125)$ \\
Env'ntal org. member & $-0.221^{*}$ & $(0.122)$ \\
Visited Svalbard & $0.772^{* * *}$ & $(0.214)$ \\
\hline D. Structural equation: Covariates of EFFECT & 0.069 & $(0.153)$ \\
Male & & \\
Age & $-0.634^{* * *}$ & $(0.166)$ \\
Age_square & $0.054^{*}$ & $(0.028)$ \\
Uni & 0.0005 & $(0.0003)$ \\
Child & -0.065 & $(0.160)$ \\
NO_Income & 0.069 & $(0.180)$ \\
Env'ntal org. member & $-0.569^{* * *}$ & $(0.188)$ \\
Visited Svalbard & $0.820^{* * *}$ & $(0.310)$ \\
\hline LL & 0.316 & $(0.223)$ \\
Number of obs. & $-4,154$ & \\
\hline Notes: ****** and * show significance level at 1\%,5\% and 10\% respectively. ${ }^{a}$ Tax amount in NOK $1,000$.
\end{tabular}

Looking at the structural equations (Sections C and D), the latent variables are linearly associated with age, with older respondents showing higher scores on both latent variables. Both latent variables are negatively associated with gender i.e. male respondents are less concerned about marine plastic pollution and are less likely to think that the initiative will be effective. Accounting for the effect of Male on the latent variables renders the negative direct effect of Male on the probability of accepting the tax in Model 1 now positive (Section A). That is, after the negative effects of Male through CONCERN and EFFECT are controlled for, being male increases the likelihood of paying the tax. This means that the main (negative) effect of Male in Model 1 operates in fact through these attitudes. Being a member of an environmental organization is associated with higher scores on CONCERN and EFFECT. By the same logic as for the variable Male, the positive effect of being member in an environmental organization on WTP (Model 1) turns insignificant when the latent variables are controlled for. It therefore seems to operate through the channel of CONCERN and EFFECT.

Estimates from Model 2 can be used to simulate WTP at different levels of the predicted latent variables (Whitehead 2006, Carson et al. 1992). All independent variables are set to their mean and WTP is simulated at the $10^{\text {th }}, 25^{\text {th }}, 50^{\text {th }}, 75^{\text {th }}$ and $90^{\text {th }}$ percentiles of each latent variable at a time (Figures $3 \mathrm{a}$ and $3 \mathrm{~b}$ ). As respondents' level of CONCERN increases from the $10^{\text {th }}$ to the $90^{\text {th }}$ percentile, simulated WTP changes from NOK 1,410 to 10,734. Respondents who score on the lowest $10^{\text {th }}$ percentile of EFFECT have a simulated WTP of NOK 2,707 compared to NOK 8,926 at the $90^{\text {th }}$ percentile. 
Figure 3: Simulation of WTP for distributions of CONCERN (3a) and EFFECT (3b)

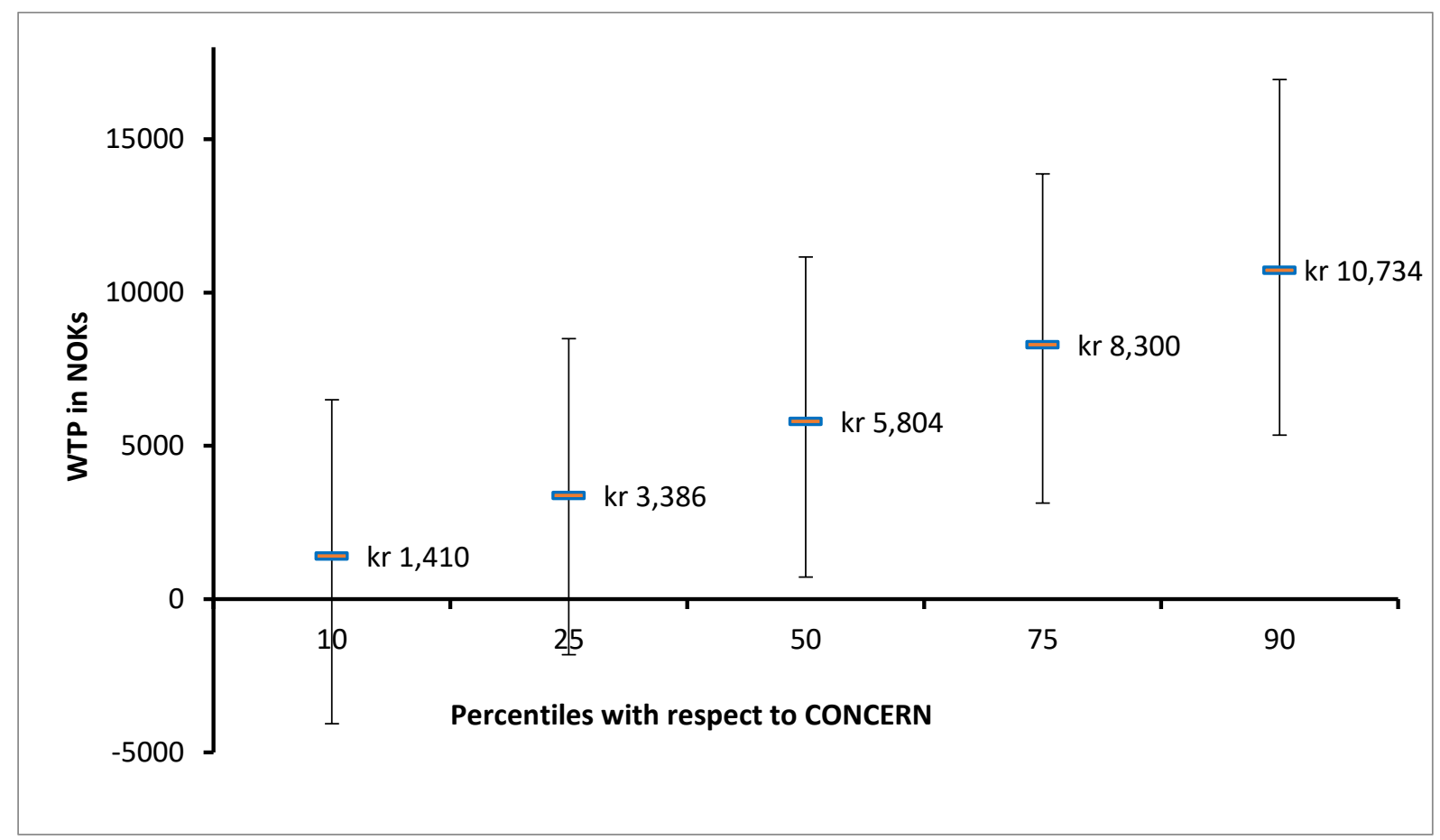

(3a)

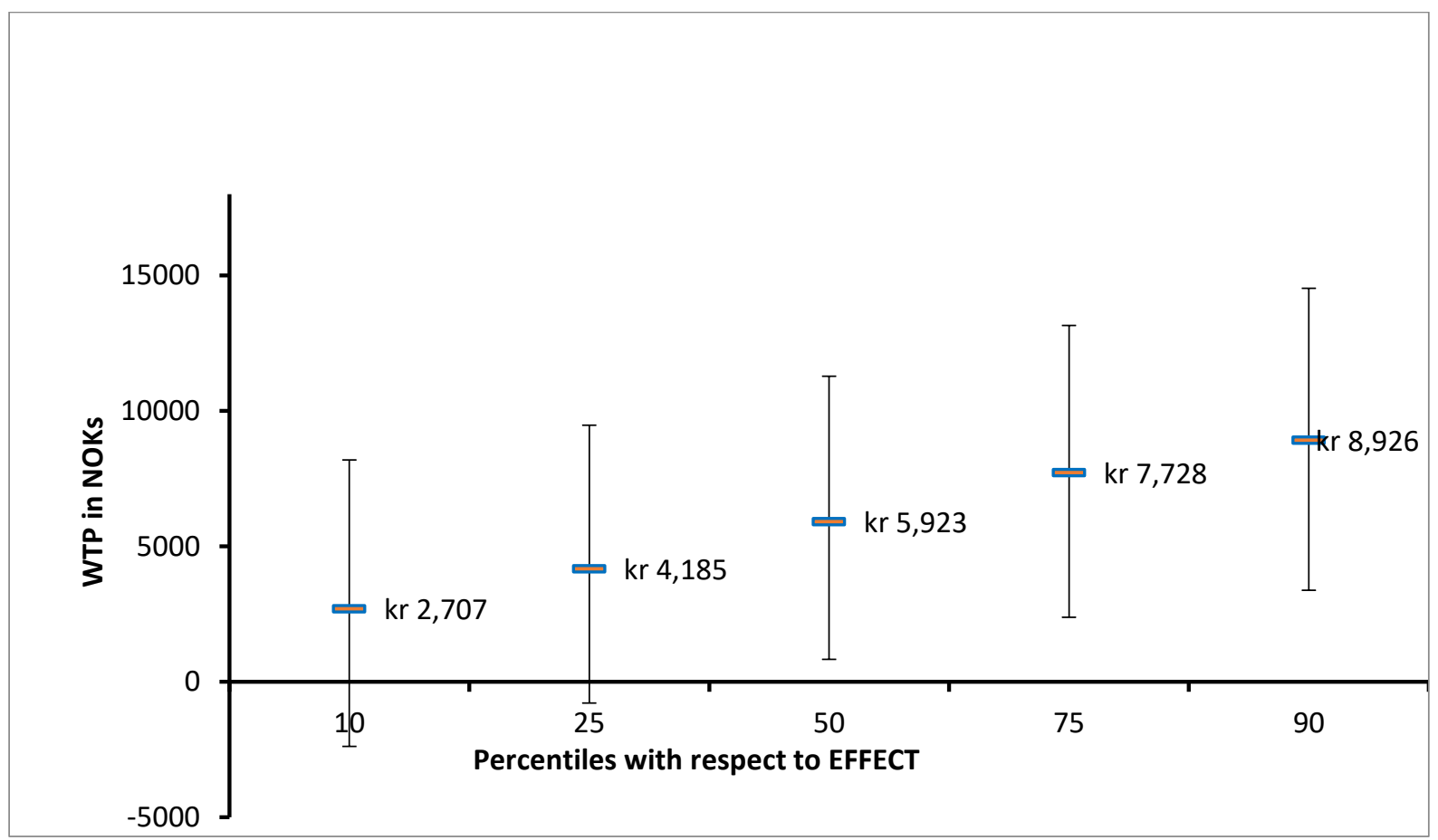

(3b)

Notes: Whiskers indicate 95\% confidence intervals bootstrapped using Krinsky and Robb (1986, 1990) procedure. 


\section{Discussion and conclusions}

This study applies the CVM to assess the benefits of reducing marine plastic pollution around the Norwegian archipelago of Svalbard in the Arctic. It finds a mean WTP for these benefits of NOK 5,485 (US\$642) per household per year, which is considerably higher than valuation in comparable studies of marine pollution reductions in the USA, such as the BP and Exxon Valdez oil spill valuation (Bishop et al., 2017; Carson et al., 1992). Moreover, compared to other previous valuation studies particularly focused on marine litter (e.g. Brouwer et al., 2017; Loomis and Santiago, 2013; Smith et al., 1997), the mean WTP is significantly higher. The mean WTP is also higher than values from comparable CVM studies in Norway (Aanesen et al., 2015; Navrud et al., 2017; Noring et al., 2016).

The WTP could be higher because the current study highlighted to respondents a range of different impacts of marine plastic pollution such as ingestion, entanglement and microplastics as well as aesthetic aspects. Responses from follow-up attitudinal questions, and the analysis based on these responses suggest two further reasons which could be responsible for the high WTP. First, most respondents are concerned about marine plastic pollution, which affects WTP positively. Many people have started to become more aware about marine litter because of the increasing attention given for marine plastic pollution in Norway. For example, in 2016 around 18,000 volunteers took part in beach clean-up activities in Norway, a number that increased to more than 90,000 volunteers in $2018^{11}$. In 2017, 1,375 tons of litter was removed through the clean-up activities registered by the non-profit organization called Keep Norway Beautiful (KNB) and the number of actions against marine litter has increased considerably in the past two years (KNB, 2017). Funding for initiatives to conduct clean-ups and implementation of preventive measures to reduce marine litter increased from NOK 20 million in 2016 to NOK 280 million in 2018. In 2018 the Norwegian Retailer's Environment Fund was also launched and reduction of plastic litter will be one of its focus areas ${ }^{12}$. The incident of a stranded beaked whale on the west-coast of Norway in 2017 with 30 plastic bags in its stomach received considerable attention in the media and substantially raised awareness of the issue for many Norwegians ${ }^{13}$. Many respondents also stated they deemed the proposed initiative important and believed in its effectiveness. These attitudes too were found to be associated with a higher likelihood to accept the proposed tax amount.

Second, the majority of respondents were evidenced to have strong beliefs that the Arctic environment should be preserved whatever the effort. The data show that only less than $10 \%$ of the respondents disagree with the statement "It is really important to take measures to reduce marine plastic litter in the Arctic whatever the cost". Krutilla (1967) argued that preservation and continued availability of a grand scenic wonder or a unique and fragile ecosystem may be a significant part of individuals' utility. The Arctic environment could qualify the uniqueness characteristic outlined by Krutilla (1967) i.e. the Arctic environment could be considered as a good with no adequate substitutes in the "natural" market area of its principal clientele. In other words, the Arctic involves the irreproducibility of unique phenomena of nature and/or the irreversibility of some consequence inimical to human welfare.

\footnotetext{
${ }^{11} \mathrm{https} / / /$ holdnorgerent.no/om-strandryddedagen/

12 https://handelensmiljofond.no/en

${ }^{13} \mathrm{https://www.telegraph.co.uk/news/2017/02/03/whale-found-dying-coast-norway-30-plastic-bags-stomach/}$
} 
The results further show that demographic variables such as gender, age and education are significant factors of WTP for reducing marine plastic in Svalbard which is in line with previous valuation studies (Brouwer et al., 2017; Smith et al., 1997). In the face of the very high WTP estimates, the fact that the relationship of the probability of accepting the tax is associated with demographic variables in this way nevertheless underlines the validity of the survey responses. Moreover, whether respondents visited Svalbard or not made no difference to their stated WTP. This could suggest the belief that the Arctic environment should be preserved for merely its existence value. However, the fact that visiting Svalbard did not make a difference on WTP could also mean that respondents may have an outward-looking attitude towards the plastics problem i.e. respondents are concerned about marine plastics in general irrespective of its location. A follow-up study to explore if changing the study site would have made any difference, e.g. to somewhere else in Norway, is recommended.

While the connection between choice and latent variable models has been intensively researched for the case of repeated, often multinomial choice data (Ben-Akiva et al., 2002; Czajkowski et al., 2017b; Hess and Beharry-Borg, 2012), its use with more traditional SBDC contingent valuation data is under-researched. The ICLV has, to the best of our knowledge, only been employed to SBDC contingent valuation data by Kassahun et al. (2016) to estimate WTP for reliable access to irrigation water for a sample of farmers in a watershed of the Ethiopian highlands. They used the ICLV model to address lack of previous irrigation experience by accounting for underlying expectations of future irrigation productivity. In this field, the ICLV approach serves two purposes: $(i)$ it accounts for measurement error in the attitudinal variables and (ii) it sheds light on the mechanisms by which some of the demographic variables affect the outcome variable. The study investigated the importance of different latent attitudes as determinants of WTP. For SBDC data this is a novel approach offering the possibility to account for attitudinal determinants of WTP while in turn simultaneously validate these concepts by identifying their observable socio-demographic determinants. For instance, the findings around concern in particular are in line with the literature on gender differences in environmental attitudes (Lee et al., 2013). This focus on the determinants of binary choice WTP responses and the more detailed analysis of these determinants strengthens the assessment of construct validity of contingent valuation data (Kling et al., 2012).

Preferences for environmental goods, such as measures to reduce marine plastic pollution are linked to attitudes held by respondents towards the environmental issue under investigation and the measures proposed to address it. The analysis of the ICLV goes beyond previous analyses of attitudinal determinants of WTP (Meyerhoff, 2006; Rosenberger et al., 2012; Sauer and Fischer, 2010). As demonstrated by the effect of Male on WTP, the ICLV approach allows for an analysis of the channel through which demographic characteristics influence WTP. Male respondents show lower levels of concern and care for the environmental issue and are less convinced of the effectiveness of the proposed initiative, which then affects WTP.

The fact that a discrete choice experiment was found to be inadequate for the valuation of these benefits during the preparatory stages and ultimately CVM was employed instead could be informative for future research in valuation of marine litter. Johnston et al. (2017) emphasized 
that the choice between attribute- versus non-attribute-based approaches should depend on 1) whether respondents think of (and value) the change in terms of individual attributes or as a whole, and 2) on the information needs of the decision makers. During piloting, it was found that respondents viewed reduction of marine plastic pollution as a package. They mentioned that it was not intuitive how the impact of marine plastic pollution could be reduced for one component of the ecosystem while the impacts on other components remain the same or increase. By and large, respondents just wanted less plastic litter around Svalbard and they seemed reluctant to tradeoff between the different impacts. This may not be aligned with the specific information needs of decision-makers. However, though more research is needed, respondents' reluctance to trade off among different impacts might have interesting consequences for future funding in marine litter research.

This study provided a novel contribution to the marine plastic pollution literature in valuing not just the aesthetic effects, but also the broader impacts. Given the results of our research, we recommend further work understanding these broader impacts to enable a more holistic understanding of the ecological, social and economic impacts of marine plastic. It is likely that the amount of plastic in the marine environment, including in the Arctic, will continue to increase, and likewise the associated impacts, so developing this understanding is critical to inform future policy and management initiatives. We also recommend the use of ICLV models to provide a detailed insight for policy making i.e. the ICLV model allows to investigate the mechanism through which demographic variables interplay with respondent attitudes and affect WTP while accounting for measurement errors.

\section{Acknowledgements}

This work was supported by the MARP project (MARine Plastic Pollution in the Arctic: origin, status, costs and incentives for Prevention), project number 257584, funded by the Polar Research programme (POLARPROG), The Norwegian Research Council of Norway. We thank Ståle Navrud and Adam Domanski for comments that greatly improved the development of the survey. 


\section{References}

Aanesen, M., Armstrong, C., Czajkowski, M., Falk-Petersen, J., Hanley, N., Navrud, S., 2015. Willingness to pay for unfamiliar public goods: Preserving cold-water coral in Norway. Ecol. Econ. 112, 53-67. https://doi.org/10.1016/j.ecolecon.2015.02.007

Aanesen, M., Falk-Andersson, J., Vondolia, G.K., Borch, T., Navrud, S., Tinch, D., 2018. Valuing coastal recreation and the visual intrusion from commercial activities in Arctic Norway. Ocean Coast. Manag. 153, 157-167. https://doi.org/10.1016/j.ocecoaman.2017.12.017

Acampora, H., Newton, S., O'Connor, I., 2017. Opportunistic sampling to quantify plastics in the diet of unfledged Black Legged Kittiwakes (Rissa tridactyla), Northern Fulmars (Fulmarus glacialis) and Great Cormorants (Phalacrocorax carbo). Mar. Pollut. Bull. 119, 171-174. https://doi.org/10.1016/j.marpolbul.2017.04.016

Ahtiainen, H., Artell, J., Czajkowski, M., Hasler, B., Hasselström, L., Huhtala, A., Meyerhoff, J., Smart, J.C.R., Söderqvist, T., Alemu, M.H., Angeli, D., Dahlbo, K., Fleming-Lehtinen, V., Hyytiäinen, K., Karlõševa, A., Khaleeva, Y., Maar, M., Martinsen, L., Nõmmann, T., Pakalniete, K., Oskolokaite, I., Semeniene, D., 2014. Benefits of meeting nutrient reduction targets for the Baltic Sea - a contingent valuation study in the nine coastal states. J. Environ. Econ. Policy 3, 278-305. https://doi.org/10.1080/21606544.2014.901923

Alvarez, S., Larkin, S.L., Whitehead, J.C., Haab, T., 2014. A revealed preference approach to valuing non-market recreational fishing losses from the Deepwater Horizon oil spill. J. Environ. Manage. 145, 199-209. https://doi.org/10.1016/j.jenvman.2014.06.031

AMAP, 2015. Summary for Policy-makers: Arctic Climate Issues 2015 | AMAP [WWW Document]. URL https://www.amap.no/documents/doc/summary-for-policy-makers-arctic-climate-issues2015/1196 (accessed 8.11.18).

Arrow, K., Solow, R., Portney, P.R., Leamer, E.E., Radner, R., Schuman, H., 1993. Report of the NOAA Panel on Contingent Valuation 67.

Atkins, J.P., Burdon, D., 2006. An initial economic evaluation of water quality improvements in the Randers Fjord, Denmark. Mar. Pollut. Bull., Recent Developments in Estuarine Ecology and Management 53, 195-204. https://doi.org/10.1016/j.marpolbul.2005.09.024

Beaumont, N.J., Aanesen, M., Austen, M.C., Börger, T., Clark, J.R., Cole, M., Hooper, T., Lindeque, P.K., Pascoe, C., Wyles, K.J., 2019. Global ecological, social and economic impacts of marine plastic. Mar. Pollut. Bull. 142, 189-195. https://doi.org/10.1016/j.marpolbul.2019.03.022

Beharry-Borg, N., Scarpa, R., 2010. Valuing quality changes in Caribbean coastal waters for heterogeneous beach visitors. Ecol. Econ. 69, 1124-1139. https://doi.org/10.1016/j.ecolecon.2009.12.007

Ben-Akiva, M., Walker, J., Bernardino, A.T., Gopinath, D.A., Morikawa, T., Polydoropoulou, A., 2002. INTEGRATION OF CHOICE AND LATENT VARIABLE MODELS. IN: IN PERPETUAL MOTION: TRAVEL BEHAVIOR RESEARCH OPPORTUNITIES AND APPLICATION CHALLENGES.

Bergmann, M., Klages, M., 2012. Increase of litter at the Arctic deep-sea observatory HAUSGARTEN. Mar. Pollut. Bull. 64, 2734-2741. https://doi.org/10.1016/j.marpolbul.2012.09.018

Bergmann, M., Lutz, B., Tekman, M.B., Gutow, L., 2017. Citizen scientists reveal: Marine litter pollutes Arctic beaches and affects wild life. Mar. Pollut. Bull. 125, 535-540. https://doi.org/10.1016/j.marpolbul.2017.09.055

Bergmann, M., Sandhop, N., Schewe, I., D’Hert, D., 2016. Observations of floating anthropogenic litter in the Barents Sea and Fram Strait, Arctic. Polar Biol. 39, 553-560. https://doi.org/10.1007/s00300-015-1795-8

Bishop, R.C., Boyle, K.J., Carson, R.T., Chapman, D., Hanemann, W.M., Kanninen, B., Kopp, R.J., Krosnick, J.A., List, J., Meade, N., Paterson, R., Presser, S., Smith, V.K., Tourangeau, R., Welsh, M., Wooldridge, J.M., DeBell, M., Donovan, C., Konopka, M., Scherer, N., 2017. Putting a value on injuries to natural assets: The BP oil spill. Science 356, 253-254. https://doi.org/10.1126/science.aam8124 
Blakemore, F., Williams, A., 2008. British Tourists' Valuation of a Turkish Beach Using Contingent Valuation and Travel Cost Methods. J. Coast. Res. 1469-1480. https://doi.org/10.2112/060813.1

Blakemore, F.B., Ozhan, E., Williams, A.T., 2000. Tourist evaluation of Olu Deniz beach (Turkey) using Contingent Valuation and Travel Cost approaches. World Leis. J. 42, 48-55. https://doi.org/10.1080/04419057.2000.9674208

Brouwer, R., Hadzhiyska, D., Ioakeimidis, C., Ouderdorp, H., 2017. The social costs of marine litter along European coasts. Ocean Coast. Manag. 138, 38-49. https://doi.org/10.1016/j.ocecoaman.2017.01.011

Buhl-Mortensen, L., Buhl-Mortensen, P., 2017. Marine litter in the Nordic Seas: Distribution composition and abundance. Mar. Pollut. Bull. 125, 260-270. https://doi.org/10.1016/j.marpolbul.2017.08.048

Carson, R.T., Groves, T., 2007. Incentive and informational properties of preference questions. Environ. Resour. Econ. 37, 181-210. https://doi.org/10.1007/s10640-007-9124-5

Carson, R.T., Groves, T., List, J.A., 2014. Consequentiality: A Theoretical and Experimental Exploration of a Single Binary Choice. J. Assoc. Environ. Resour. Econ. 1, 171-207. https://doi.org/10.1086/676450

Carson, R.T., Mitchell, R.C., Hanemann, M., Kopp, R.J., Presser, S., Ruud, P.A., 2003. Contingent Valuation and Lost Passive Use: Damages from the Exxon Valdez Oil Spill. Environ. Resour. Econ. 25, 257-286. https://doi.org/10.1023/A:1024486702104

Carson, R.T., Mitchell, R.C., H'memann, W.M., Kopp, R.J., 1992. A Contingent Valuation Study of Lost Passive Use Values Resulting from the Exxon Valdez Oil Spill. Rep. Atty. Gen. State Alsk. Nat. Resour. Damage Assess. Inc 133.

Cole, M., Lindeque, P., Fileman, E., Halsband, C., Goodhead, R., Moger, J., Galloway, T.S., 2013. Microplastic Ingestion by Zooplankton. Environ. Sci. Technol. 47, 6646-6655. https://doi.org/10.1021/es400663f

Czajkowski, M., Hanley, N., Nyborg, K., 2017a. Social Norms, Morals and Self-interest as Determinants of Pro-environment Behaviours: The Case of Household Recycling. Environ. Resour. Econ. 66, 647-670. https://doi.org/10.1007/s10640-015-9964-3

Czajkowski, M., Vossler, C.A., Budziński, W., Wiśniewska, A., Zawojska, E., 2017b. Addressing empirical challenges related to the incentive compatibility of stated preferences methods. J. Econ. Behav. Organ. 142, 47-63. https://doi.org/10.1016/j.jebo.2017.07.023

Egan, K.J., Corrigan, J.R., Dwyer, D.F., 2015. Three reasons to use annual payments in contingent valuation surveys: Convergent validity, discount rates, and mental accounting. J. Environ. Econ. Manag. 72, 123-136. https://doi.org/10.1016/j.jeem.2015.05.002

Falk-Andersson, J., Berkhout, B.W., Abate, T.G., 2019. Citizen science for better management: Lessons learned from three Norwegian beach litter data sets. Mar. Pollut. Bull. 138, 364-375. https://doi.org/10.1016/j.marpolbul.2018.11.021

Fife, D.T., Robertson, G.J., Shutler, D., Braune, B.M., Mallory, M.L., 2015. Trace elements and ingested plastic debris in wintering dovekies (Alle alle). Mar. Pollut. Bull. 91, 368-371. https://doi.org/10.1016/j.marpolbul.2014.11.029

Ford, J.D., Smit, B., Wandel, J., 2006. Vulnerability to climate change in the Arctic: A case study from Arctic Bay, Canada. Glob. Environ. Change 16, 145-160. https://doi.org/10.1016/j.gloenvcha.2005.11.007

Grilli, G., Notaro, S., Campbell, D., 2018. Including Value Orientations in Choice Models to Estimate Benefits of Wildlife Management Policies. Ecol. Econ. 151, 70-81. https://doi.org/10.1016/j.ecolecon.2018.04.035

Haab, T.C., McConnell, K.E., 2003. Valuing Environmental and Natural Resources: The Econometrics of Non-Market Valuation. Edward Elgar Publishing Ltd, Cheltenham.

Hallanger, I., Gabrielsen, G.W., 2018. Plastic in the European Arctic (No. Kortrapport 045 (2018)). Halpern, B.S., Walbridge, S., Selkoe, K.A., Kappel, C.V., Micheli, F., D’Agrosa, C., Bruno, J.F., Casey, K.S., Ebert, C., Fox, H.E., Fujita, R., Heinemann, D., Lenihan, H.S., Madin, E.M.P., Perry, M.T., Selig, E.R., Spalding, M., Steneck, R., Watson, R., 2008. A Global Map of Human Impact on Marine Ecosystems. Science 319, 948-952. https://doi.org/10.1126/science.1149345 
Hanemann, W.M., 1984. Welfare Evaluations in Contingent Valuation Experiments with Discrete Responses. Am. J. Agric. Econ. 66, 332. https://doi.org/10.2307/1240800

Hess, S., Beharry-Borg, N., 2012. Accounting for Latent Attitudes in Willingness-to-Pay Studies: The Case of Coastal Water Quality Improvements in Tobago. Environ. Resour. Econ. 52, 109-131. https://doi.org/10.1007/s10640-011-9522-6

Jambeck, J.R., Geyer, R., Wilcox, C., Siegler, T.R., Perryman, M., Andrady, A., Narayan, R., Law, K.L., 2015. Plastic waste inputs from land into the ocean. Science 347, 768-771. https://doi.org/10.1126/science.1260352

Johnston, R.J., Boyle, K.J., Adamowicz, W. (Vic), Bennett, J., Brouwer, R., Cameron, T.A., Hanemann, W.M., Hanley, N., Ryan, M., Scarpa, R., Tourangeau, R., Vossler, C.A., 2017. Contemporary Guidance for Stated Preference Studies. J. Assoc. Environ. Resour. Econ. 4, 319-405. https://doi.org/10.1086/691697

Kanninen, B.J. (Ed.), 2007. Valuing Environmental Amenities Using Stated Choice Studies: A Common Sense Approach to Theory and Practice, The Economics of Non-Market Goods and Resources. Springer Netherlands.

Kassahun, H.T., Nicholson, C.F., Jacobsen, J.B., Steenhuis, T.S., 2016. Accounting for user expectations in the valuation of reliable irrigation water access in the Ethiopian highlands. Agric. Water Manag. 168, 45-55. https://doi.org/10.1016/j.agwat.2016.01.017

Kling, C.L., Phaneuf, D.J., Zhao, J., 2012. From Exxon to BP: Has Some Number Become Better Than No Number? J. Econ. Perspect. 26, 3-26. https://doi.org/10.1257/jep.26.4.3

Krinsky, I., Robb, A.L., 1990. On Approximating the Statistical Properties of Elasticities: A Correction. Rev. Econ. Stat. 72, 189-190. https://doi.org/10.2307/2109761

Krinsky, I., Robb, A.L., 1986. On Approximating the Statistical Properties of Elasticities. Rev. Econ. Stat. 68, 715-719. https://doi.org/10.2307/1924536

Krutilla, J.V., 1967. Conservation Reconsidered. Am. Econ. Rev. 57, 777-786.

Lee, E., Park, N.-K., Han, J.H., 2013. Gender Difference in Environmental Attitude and Behaviors in Adoption of Energy-Efficient Lighting at Home. J. Sustain. Dev. 6. https://doi.org/10.5539/jsd.v6n9p36

Lee, H.-J., Kim, H.-J., Yoo, S.-H., Lee, H.-J., Kim, H.-J., Yoo, S.-H., 2018. The Public Value of Reducing the Incidence of Oil Spill Accidents in Korean Rivers. Sustainability 10, 1172. https://doi.org/10.3390/su 10041172

Lindhjem, H., Navrud, S., 2009. Asking for Individual or Household Willingness to Pay for Environmental Goods? Environ. Resour. Econ. 43, 11-29. https://doi.org/10.1007/s10640-0099261-0

Liu, X., Pan, G., Wang, Y., Yu, X., Hu, X., Zhang, H., Tang, C., 2016. Public Attitudes on Funding Oil Pollution Cleanup in the Chinese Bohai Sea. J. Coast. Res. 74, 207-213. https://doi.org/10.2112/SI74-018.1

Loomis, J., Santiago, L., 2013. Economic Valuation of Beach Quality Improvements: Comparing Incremental Attribute Values Estimated from Two Stated Preference Valuation Methods. Coast. Manag. 41, 75-86. https://doi.org/10.1080/08920753.2012.749754

Loomis, J., Traynor, K. and Brown, T. (1999) Trichotomous choice: A possible solution to dual response objective in dichotomous choice contingent valuation questions. Journal of Agricultural and Applied Economics 24(2), 572-583.

Loureiro, M.L., Loomis, J.B., Vázquez, M.X., 2009. Economic Valuation of Environmental Damages due to the Prestige Oil Spill in Spain. Environ. Resour. Econ. 44, 537-553. https://doi.org/10.1007/s10640-009-9300-x

Lusher, A.L., Tirelli, V., O'Connor, I., Officer, R., 2015. Microplastics in Arctic polar waters: the first reported values of particles in surface and sub-surface samples. Sci. Rep. 5, 14947. https://doi.org/10.1038/srep14947

Lusk, J.L. and Norwood, F.B. (2009) An Inferred Valuation Method. Land Economics 85(3), 500514.

Meyerhoff, J., 2006. Stated willingness to pay as hypothetical behaviour: Can attitudes tell us more? J. Environ. Plan. Manag. 49, 209-226. https://doi.org/10.1080/09640560500507959 
Min, S.-H., Lim, S.-Y., Yoo, S.-H., 2017. The environmental benefits of reducing thermal discharge from nuclear power generation. Energy Environ. 28, 885-894. https://doi.org/10.1177/0958305X17734049

Mitchell, R.C., Carson, R.T., 1989. Using Surveys to Value Public Goods: The Contingent Valuation Method. Resources for the Future.

Navrud, S., Lindhjem, H., Magnussen, K., 2017. , in: Svensson, L., Markandya, A. (Eds.), Valuing Marine Ecosystem Services Loss from Oil Spills for Use in Cost-Benefit Analysis of Preventive Measures. Edward Elgar Publishing, pp. 124-137. https://doi.org/10.4337/9781786430724

Newman, S., Watkins, E., Farmer, A., Brink, P. ten, Schweitzer, J.-P., 2015. The Economics of Marine Litter, in: Bergmann, M., Gutow, L., Klages, M. (Eds.), Marine Anthropogenic Litter. Springer International Publishing, Cham, pp. 367-394. https://doi.org/10.1007/978-3-31916510-3_14

Noring, M., Hasselström, L., Håkansson, C., Soutukorva, Å., Gren, Å., 2016. Valuation of oil spill risk reductions in the Arctic. J. Environ. Econ. Policy 5, 298-317. https://doi.org/10.1080/21606544.2016.1155499

Obbard, R.W., Sadri, S., Wong, Y.Q., Khitun, A.A., Baker, I., Thompson, R.C., 2014. Global warming releases microplastic legacy frozen in Arctic Sea ice. Earths Future 2, 315-320. https://doi.org/10.1002/2014EF000240

Östberg, K., Hasselström, L., Håkansson, C., 2012. Non-market valuation of the coastal environment - Uniting political aims, ecological and economic knowledge. J. Environ. Manage. 110, 166178. https://doi.org/10.1016/j.jenvman.2012.06.012

Petrolia, D.R., 2015. What Have We Learned from the Deepwater Horizon Disaster? An Economist's Perspective (SSRN Scholarly Paper No. ID 3179112). Social Science Research Network, Rochester, NY.

Poon, F.E., Provencher, J.F., Mallory, M.L., Braune, B.M., Smith, P.A., 2017. Levels of ingested debris vary across species in Canadian Arctic seabirds. Mar. Pollut. Bull. 116, 517-520. https://doi.org/10.1016/j.marpolbul.2016.11.051

Provencher, J.F., Gaston, A.J., Mallory, M.L., O'hara, P.D., Gilchrist, H.G., 2010. Ingested plastic in a diving seabird, the thick-billed murre (Uria lomvia), in the eastern Canadian Arctic. Mar. Pollut. Bull. 60, 1406-1411. https://doi.org/10.1016/j.marpolbul.2010.05.017

Rodrigues, L.C., van den Bergh, J.C.J.M., Ghermandi, A., 2013. Socio-economic impacts of ocean acidification in the Mediterranean Sea. Mar. Policy 38, 447-456. https://doi.org/10.1016/j.marpol.2012.07.005

Rosenberger, R.S., Needham, M.D., Morzillo, A.T., Moehrke, C., 2012. Attitudes, willingness to pay, and stated values for recreation use fees at an urban proximate forest. J. For. Econ., Non-market valuation 18, 271-281. https://doi.org/10.1016/j.jfe.2012.06.003

SALT, 2017. report_wp_1.2_waste_workshop_.pdf (No. 1017), Sources of Marine Litter" -Workshop Report, Svalbard 4th -6th September 2016.

Sauer, U., Fischer, A., 2010. Willingness to pay, attitudes and fundamental values - On the cognitive context of public preferences for diversity in agricultural landscapes. Ecol. Econ. 70, 1-9. https://doi.org/10.1016/j.ecolecon.2010.03.026

Smith, V.K., Zhang, X., Palmquist, R.B., 1997. Marine Debris, Beach Quality, and Non-Market Values. Environ. Resour. Econ. 10, 223-247. https://doi.org/10.1023/A:1026465413899

Sun, X., Li, Q., Zhu, M., Liang, J., Zheng, S., Zhao, Y., 2017. Ingestion of microplastics by natural zooplankton groups in the northern South China Sea. Mar. Pollut. Bull. 115, 217-224. https://doi.org/10.1016/j.marpolbul.2016.12.004

Svenson, J., 2013. MabCent: Arctic marine bioprospecting in Norway. Phytochem. Rev. 12, 567-578. https://doi.org/10.1007/s11101-012-9239-3

Taye, F.A., Vedel, S.E., Jacobsen, J.B., 2018. Accounting for environmental attitude to explain variations in willingness to pay for forest ecosystem services using the new environmental paradigm. J. Environ. Econ. Policy 7, 420-440.

https://doi.org/10.1080/21606544.2018.1467346 
Taylor, T., Longo, A., 2010. Valuing algal bloom in the Black Sea Coast of Bulgaria: A choice experiments approach. J. Environ. Manage. 91, 1963-1971. https://doi.org/10.1016/j.jenvman.2010.04.007

Tekman, M.B., Krumpen, T., Bergmann, M., 2017. Marine litter on deep Arctic seafloor continues to increase and spreads to the North at the HAUSGARTEN observatory. Deep Sea Res. Part Oceanogr. Res. Pap. 120, 88-99. https://doi.org/10.1016/j.dsr.2016.12.011

Thevenon, F., Carroll, C., Sousa, J. (Eds.), 2015. Plastic debris in the ocean: the characterization of marine plastics and their environmental impacts, situation analysis report. International Union for Conservation of Nature. https://doi.org/10.2305/IUCN.CH.2014.03.en

Trevail, A.M., Gabrielsen, G.W., Kühn, S., Van Franeker, J.A., 2015a. Elevated levels of ingested plastic in a high Arctic seabird, the northern fulmar (Fulmarus glacialis). Polar Biol. 38, 975981. https://doi.org/10.1007/s00300-015-1657-4

Trevail, A.M., Kühn, S., Gabrielsen, G.W., 2015b. The state of marine microplastic pollution in the Arctic.

Van Biervliet, K., Le Roy, D., Nunes, P.A.L.D., 2005. A Contingent Valuation Study of an Accidental Oil Spill Along the Belgian Coast, in: Maes, F. (Ed.), Marine Resource Damage Assessment. Springer Netherlands, Dordrecht, pp. 165-207. https://doi.org/10.1007/1-40203368-0_8

Wyles, K.J., Pahl, S., Thomas, K., Thompson, R.C., 2016. Factors That Can Undermine the Psychological Benefits of Coastal Environments: Exploring the Effect of Tidal State, Presence, and Type of Litter. Environ. Behav. 48, 1095-1126. https://doi.org/10.1177/0013916515592177

Zawojska, E., Bartczak, A., Czajkowski, M., 2019. Disentangling the effects of policy and payment consequentiality and risk attitudes on stated preferences. J. Environ. Econ. Manag. 93, 63-84. https://doi.org/10.1016/j.jeem.2018.11.007

Żylicz, T., 1995. Contingent Valuation of Eutrophication Damage in the Baltic Sea Region, Centre for Social and Economic Research on the Global Environment working paper GEC. CSERGE. 